\title{
Market-Driving Strategy and Personnel Attributes: Top Management versus Middle Management
}

\begin{abstract}
:
This study focuses on the role that personnel attributes play during the implementation of a market-driving strategy, a topic that has heretofore received limited academic attention. Contrary to the traditional reactive market-driven approach, the proactive market-driving approach pertains to influencing the market structure and/or the market players' behavior in a direction that enhances the firm's competitive posture. Using a qualitative research design, it is empirically demonstrated for the first time that specific characteristics of the top management (i.e., open-minded policy, strong vision, strategic human resource management, transformational leadership, prediction skills and insightfulness, fostering creativity), as well as certain traits of middle-level employees (i.e., open-minded policy, transformational leadership, creativity, expertise, intrapreneurship, commitment, flexibility) are of central importance to the marketdriving concept. Relevant research propositions are formulated and their respective implications are discussed.
\end{abstract}

\section{Keywords:}

Market-Driving Strategy, Market Orientation, Personnel Attributes, Top Management, MiddleLevel Employees

This research did not receive any specific grant from funding agencies in the public, commercial, or not-for-profit sectors. 


\section{Market-Driving strategy and Personnel Attributes: Top Management versus Middle Management}

\section{Introduction}

Customer centricity has been a core concept in marketing for several decades. In fact, nowadays, customer centricity has become a basic prerequisite for every firm aspiring to obtain a paramount competitive edge in any market (Shah, Rust, Parasuraman, Staelin, \& Day, 2006). In an effort to enrich this concept, theories have been developed, such as those of market orientation (i.e., information generation, information dissemination, and responsiveness) (Kohli \& Jaworski, 1990) and market-driven organizations (i.e., firms who sense and act on trends in their markets, without attempting to alter market conditions) (Day, 1994). Such theories have further clarified the importance of being oriented not only toward the customer (Angulo-Ruiz, Donthu, Prior, \& Rialp, 2014), but also toward other stakeholders (Carrillat, Jaramilo, \& Locander, 2004).

However, more recently, scholars have begun criticizing the classic market-orientation conceptualization as being excessively responsive toward market conditions and as overemphasizing current customer needs, thereby neglecting latent ones (Chen, Li, \& Evans, 2012; Hills \& Sarin, 2003). Furthermore, the classic definition of market orientation fails to clarify the strategic moves of market players who behave proactively, shape the "status quo" of their industries, and change the so-called "rules of the game." Additionally, within any given market, if all market players were to adopt a responsive market-driven philosophy, no firm would eventually obtain a competitive advantage (Neuenburg, 2010). Indeed, the foregoing arguments indicate that, despite its unquestionable impact (e.g., Foltean \& Feder, 2009; Najafi-Tavani, Sharifi, \& Najafi-Tavani, 2016; Raju, Lonial, \& Crum, 2011; Zhou, Brown, \& Dev, 2009), the 
classic approach toward market orientation is conceptually incomplete. Such a shortcoming has been tackled through the development of the market-driving strategy concept, defined as an influence over the structure of the market and/or the behavior(s) of market players in a direction that enhances the competitive position of the business (Jaworski, Kohli, \& Sahay, 2000).

To date, market orientation has received noteworthy scholarly attention (Kirca, Jayachandran, \& Bearden, 2005). However, most of the research conducted so far has unilaterally concentrated on market-driven strategy. Furthermore, this research has left important gaps concerning the clarification of important practical issues, such as the identification of certain antecedents to this strategy (Ghauri, Wang, Elg, \& Rosendo-Ríos, 2016). More specifically, little is known about the role that personnel attributes play in the implementation of market-driving strategy implementation. For instance, important questions remain unanswered, such as: "What are the prominent characteristics of top management that facilitate the implementation of market-driving strategy?" and "What are the traits of middle-level employees that reinforce implementation of this strategy?" The research project at hand responds to these challenging queries with the aim of filling the respective research gaps.

In this regard, the overall scope of the study is encompassed within the broader body of literature linking market orientation and personnel characteristics (e.g., Lancaster \& Van Der Velden, 2004; Kirca et al., 2005). Moreover, its precise objectives are to identify the most important characteristics (1) of top management, and (2) of middle-level employees that facilitate the implementation of market-driving strategy. In particular, the study focuses on certain aspects, namely, skills and personality traits of top management and middle-level employees that are closely related to the market-driving concept (including vision, prediction skills and insightfulness, creativity, expertise, and flexibility). This means that, adopting a funnel 
approach, we begin our inquiry from the relationship between market orientation and personnel characteristics; we then narrow our focus to the interplay between market-driving strategy and personnel characteristics; and we conclude with the relevant personnel attributes that comprise the principal findings and borderlines of our study.

Overall, our research contributes to the literature in the following ways. (1) To the best of our knowledge, this is the first study to focus on the importance of personnel characteristics in the field of market-driving strategy. (2) This is the only study to shed light on both top and middle organizational levels, contrasting one with the other and identifying their commonalities and differences. (3) This is the first time that specific traits of top management (i.e., openminded policy, strong vision, strategic human resource management, transformational leadership, prediction skills and insightfulness, and fostering creativity) and characteristics of middle-level employees (i.e., open-minded policy, transformational leadership, creativity, expertise, intrapreneurship, commitment, and flexibility), are highlighted as antecedents of market-driving strategy. (4) This study is the first to provide empirical findings verifying previous theoretical arguments which emphasized the importance for the market-driving concept of factors such as creativity (Kumar, Scheer, \& Kotler, 2000), transformational leadership (Carrillat et al., 2004), and flexibility (Johnson, Lee, Saini, \& Grohmann, 2003). (5) Moreover, our findings empirically affirm for the first time the theoretical notion that market-driven and market-driving strategies have a subset of antecedents in common (Neuenburg, 2010). (6) Finally, by bringing the role of intrapreneurship to the fore, we significantly extend the work of Schindehutte, Morris, and Kocak (2008), Zortea-Johnston, Darroch, and Matear (2012), and Chen et al. (2012), who linked market-driving strategy with the concept of entrepreneurship. 


\section{Theoretical background}

\subsection{The market orientation domain}

The idea of being market-oriented is not new. Drucker (1954) was among the first to highlight the importance of the customer as the focal point of business practice. Subsequently, a series of articles has been published on the subject. By considering all streams of the literature, it becomes evident that the market orientation domain (e.g., Foltean \& Feder, 2009; Urde, Baumgarth, \& Merrilees, 2013) can be described as a spectrum consisting of three facets. The first facet, known as the market-driven strategy, refers to a traditional business strategy grounded in understanding and reacting to the preferences and behaviors of players within a given market structure (Jaworski et al., 2000). The second facet, termed market-driving strategy, pertains to influencing the structure of the market or the behavior(s) of market players in a direction that enhances the competitive posture of the business (Jaworski et al., 2000). Finally, the third facet, named proactive market orientation (Herhausen, 2016; Narver, Slater, \& MacLachlan, 2004) represents the type of market orientation that seeks to understand and satisfy both articulated and latent needs, yet without altering market conditions (Neuenburg, 2010).

\subsection{Market-driving strategy}

Market-driving strategy reflects a firm's ability to drive fundamental changes as to the evolution of conditions within a particular industry. Contrary to firms that employ a marketdriven or a proactive market-orientation approach, firms that adopt a market-driving approach, also known as "market drivers," behave proactively by educating and leading their customers, thereby shaping the behavior of those customers. In addition, such firms fundamentally modify or create new markets, ultimately changing the "rules of the game" or influencing the evolution 
of their industry, rather than passively responding to such evolution (Chen et al., 2012; Harris \& Cai, 2002). Thus, instead of giving customers what they want, market drivers educate customers to "learn" what they want (Carpenter, Glazer, \& Nakamoto, 2001). Therefore, market drivers emphasize not only customers' denoted needs but also their latent needs (Hills \& Sarin, 2003). The strategy of enterprises such as IKEA, Starbucks, De Beers, Sony, Amazon.com, Apple, Virgin, Walmart, and Benetton (Filieri, 2015; Schindehutte et al., 2008), for example, has been characterized over the years by revolutionary business models, disruptive innovation, and a discontinuous leap in the value proposition, all of which are prominent traits of a market-driving strategy (Kumar et al., 2000).

\subsection{The role of top management in a market-driving firm}

Despite the profound importance of the top management team in every market-oriented firm (Jaworski \& Kohli, 1993; Kirca et al., 2005), its characteristics have received scant attention within a market-driving firm context. First, in this context, the top management team is responsible for establishing a culture of creativity, entrepreneurship, and innovativeness (Blut, Holzmüller, \& Stolper, 2012; Chen et al., 2012; Zortea-Johnston et al., 2012). Second, from a conceptual standpoint, the top management is responsible for empowering latent entrepreneurs, approving new ideas, establishing competitive teams, and tolerating mistakes within the firm (Kumar et al., 2000). Third, the importance of transformational leadership and an adhocracy type of culture (i.e. external/informal) have already been emphasized theoretically (Carrillat et al., 2004). Finally, the top management team is basically responsible for developing an array of organizational capabilities within the firm, namely configuration, networking, knowledge transfer, internal branding, and learning (Ghauri et al., 2016; Storbacka \& Nenonen, 2015). 


\subsection{Investigating 10 characteristics of top management}

In order to sufficiently map the most important top management and middle management characteristics, we broke down our overarching research objective into two distinguishable subobjectives: the "unaided" objective, the disclosure of respondents' spontaneous opinions regarding the characteristics that top management and middle-level employees should have in a market-driving firm; and the "aided" objective, the disclosure of respondents' beliefs in response to two shortlists of potentially relevant characteristics that top management and middle-level employees should have in such a firm. In order to approach the latter objective, we created a shortlist of 10 potential top management characteristics: (1) transformational leadership, (2) fostering creativity, (3) fostering open-mindedness, (4) fostering freedom of opinion-sharing, (5) fostering risk-taking, (6) encouraging new idea generation, (7) tolerating mistakes, (8) having strong corporate vision, (9) encouraging participative decision-making, and (10) keeping the locus of decision-making close to customers. Information about the definitions of these characteristics and their relevance to market-driving strategy is included in Table 1.

- Insert Table 1 about here -

We decided to test this shortlist in an effort to narrow the focus of our investigation and to triangulate and cross-validate the dimensions of the interviews via the various questions asked (Flick, 2004; Thurmond, 2001). While the above shortlist is not exhaustive, it comprises a first exploratory step toward producing interesting insights on the topic. These specific characteristics were chosen on the basis of the following criteria: (1) parsimony, so that a feasible number of characteristics could be tested; (2) potential relevance, so that the chosen characteristics were notionally related to the market-driving concept; (3) necessity for theory testing, meaning that we selected characteristics grounded in conceptual studies of market-driving strategy (e.g., Kumar, 
Scheer, \& Kotler, 2000); acknowledging the need for empirical verification for the first time in the field of the importance of such characteristics; (4) potential contribution, meaning that we chose specific characteristics from the broader management literature whose relevance to the market-driving concept has not been tested before; and (5) research interest, meaning that we focused on constructs that overlap with our scientific concerns.

\subsection{The role of middle-level employees in a market-driving firm}

Perhaps the most critical sources of competitive advantage for any firm are its human resources across all organizational levels (Pfeffer, 1995). The same applies to the successful implementation of market-driving strategy. Along such lines, theorists have underlined the importance of encouraging employees to demonstrate creativity, generate new ideas, and act as latent entrepreneurs within the firm (Kumar et al., 2000). Moreover, it has been conceptually demonstrated that the human factor is crucial in creating a market-driving culture, since hiring, retaining, and training individuals with transformational leadership skills are factors of high significance (Carrillat et al., 2004). In addition, there have been assertions regarding the importance of entrepreneurial human capital, as well as the employees' ability to determine change for the market-driving approach (Blut et al., 2012; Van Vuuren \& Wörgötter, 2013). Finally, the employees' participative role in co-creating market-driving strategy has been stressed. In particular, Tarnovskaya, Elg, and Burt (2008), who focused on IKEA, explained that the establishment of market-driving strategy started from the inside, since IKEA's employees personified the firm's vision and values, while their competencies facilitated the firm's strategy. 


\subsection{Investigating 10 characteristics of middle-level employees}

Similar to the procedure followed for top management, we created a shortlist of 10 potential characteristics of middle-level employees: (1) transformational leadership, (2) intrapreneurship, (3) creativity, (4) self-confidence, (5) commitment, (6) risk-taking, (7) individual adaptability, (8) competitiveness, (9) flexibility, and (10) open-mindedness. The criteria we used to select these specific characteristics were the same as those used for top management (see section 2.4). Information about the respective definitions and the relevance of these concepts to market-driving strategy is summarized in Table 2.

- Insert Table 2 about here -

\section{Research methodology}

In order to approach our topic empirically, we adopted an exploratory qualitative research design by conducting in-depth interviews. It is notable that no empirical study has so far been published that investigates the relationship of personnel attributes within the market-driving research area. Consequently, an exploratory research design and, more precisely, in-depth interviewing is a suitable approach, given that existing knowledge on the topic is limited (Graebner, Martin, \& Roundy, 2012; Pratt, 2009). Indeed, Creswell (2008) explains that if a concept or phenomenon needs to be understood because little research has been done on it, then it merits a qualitative approach, while Morse (1991) further endorses qualitative designs as appropriate when the topic is new or has never been addressed with a certain group of people.

In particular, we interviewed 27 experts who, through their daily work experiences, have in-depth knowledge on market-driving strategy. In an attempt to incorporate the insights of both 
academics and practitioners, the key respondents chosen comprised seven academic experts and 20 higher-level marketing executives of market-driving firms. The respondents' average working experience was more than 16 years. The qualitative study was conducted in Greece. Greece was selected as an appropriate setting for the study, given the turbulent specificities and contextual factors of its markets (Matsaganis, 2011; Zavras, Tsiantou, Pavi, Mylona, \& Kyriopoulos, 2012). According to Blut et al. (2012) and Neuenburg (2010), market turbulence and technology turbulence act as principal moderators of the relationship between market-driving strategy and performance. Therefore, turbulent environments trigger the development of market-driving firms. Twenty interviews were conducted between fall 2016 and winter 2017, while seven additional interviews were performed in the spring of 2018. Considering the specificities of both the topic and the local market (e.g., shortage of an accurate sampling frame), a purposive sampling methodology was implemented combined with the snowball technique (Parasuraman, Grewal, \& Krishnan, 2004). We concluded data collection when we reached a saturation point (Dworkin, 2012) (i.e., the point at which very little new evidence was obtained from each additional fieldwork unit). The duration of the interviews ranged from 50 to 115 minutes, with an average of approximately 77 minutes. Table 3 provides information about the profiles of the 20 firms and their relevance to the market-driving concept.

- Insert Table 3 about here -

A semi-structured interview format was employed, which allowed us to ask a standard set of questions and to react with relevant probing techniques (Daymon \& Holloway, 2010), dependent upon the interviewees' responses. The interviews were based on an interview guide that covered a broad array of aspects regarding market-driving strategy. The interview guide was developed by following established guidelines (Mason, 2002; Rowley, 2012). It was revised by 
seven academic experts, and was extensively pretested until corrections reached a saturation point (i.e., a point after which responses didn't provide any additional insight).

In the introductory part of the interview guide, the definition of market-driving strategy and several examples of market-driving firms were discussed with the interviewees. Building further on our respective research objectives, four broad sections of questions were asked. Section A1 was an unaided, "grand tour" section (Daymon \& Holloway, 2010), where respondents were directly asked to spontaneously provide their opinions about the characteristics that top management in a market-driving firm should have. A2 comprised an aided "mini tour" section (Daymon \& Holloway, 2010), where a shortlist including the foregoing 10 top management characteristics was verbally described to the respondents. Then, each respondent was asked to comment on the role of each of those characteristics for a market-driving firm and to justify his/her opinion. B1 formed an unaided, "grand tour" section, where respondents were directly asked to spontaneously outline their standpoints on the characteristics that middle-level employees should have in a market-driving firm. Finally, B2 was an aided "mini tour" section, where a shortlist including the abovementioned 10 middle-level employee characteristics was verbally described to the respondents. As in section A2, each respondent was asked to comment on the significance of each of those characteristics for a market-driving firm, and justify his/her opinion. The phrasing used throughout the interview process was grounded in extant theory and definitions of the relevant constructs. Special attention was paid by the interviewers to ensuring that the respondents answered each section in a fully unbiased way. For example, in sections A2 and B2, respondents had full freedom to elaborate on and to accept or decline the role of each characteristic (i.e., as favorable, unfavorable, or neutral) without any misleading restrictions. 


\section{Data analysis}

The interviews were tape recorded, transcribed verbatim, and anonymized. Adopting previously established guidelines (Miles \& Huberman, 1994; Schreier, 2012; Strauss \& Corbin, 1998), we analyzed the qualitative data by implementing the analytical technique of qualitative content analysis (Krippendorff, 2004; Schreier, 2014). The interview material was analyzed by generating categories in an inductive (data-driven) way, as proposed by Schreier (2012). All interviews were coded in accordance with the coding frame resulting from the inductively generated categories. As a starting point, we analyzed each interview separately. Next, we compared the interviews across categories to identify similarities, differences, and patterns. In general, data analysis was carried out in an iterative cyclic fashion, going back and forth between the qualitative data and the emerging structure of the theoretical arguments (Daymon \& Holloway, 2010; Schreier, 2012).

In order to account for the reliability of the coding procedure, two independent coders collaborated, following a blind coding procedure. The overall coefficient of agreement between the two coders for all units of coding was $95.41 \%$. However, a simple coefficient of agreement usually overestimates actual agreement, given that it does not take into account the possibility of agreement by chance alone. To address this concern, we calculated Cohen's kappa coefficient of agreement for each section of the transcripts. Sections A1, A2, B1, and B2 had kappa coefficients of $93.4 \%, 91.3 \%, 91.0 \%$, and $93.6 \%$, respectively_-values that exceed the suggested 80\% threshold (Krippendorff, 2004; Neuendorf, 2002; Popping, 1988) and indicate satisfactory intercoder reliability. Disagreements were addressed by the two coders debating and jointly resolving discrepancies. With regard to the validity of the coding frame, the inductive method of coding is one way in which to ensure that the coding frame captures what it sets out to capture 
(Schreier, 2012). In addition, face validity was enhanced in the following four ways: (1) a pilot coding procedure was part of the cyclic coding process, which improved the accuracy of the coding frame; (2) the residual categories had low coding frequencies compared to the other subcategories; (3) no subcategory had extremely high frequency compared to the other subcategories; (4) the level of abstraction employed to summarize and reduce the material was kept to a medium level, and the coding frame was not underdifferentiated (Schreier, 2012).

\section{Findings, conceptual framework, and research propositions}

Intriguing consistent commonalities across participants emerged from all sections of questions asked. Our principal findings are summarized in Table 4.

- Insert Table 4 about here -

Grounded in the response patterns, it became evident that some traits are equally important for both top management and middle management levels, while certain other traits have varying significance depending on the organizational level. In other words, certain characteristics appear to overlap and have "universal importance" for market-driving firms, spanning across organizational levels, while at the same time other traits appear to have different weights and magnitudes for top management compared to middle management. Building upon these findings, we developed the conceptual framework depicted in Figure 1.

- Insert Figure 1 about here -

We now proceed to the presentation of our principal results and formulate our respective research propositions. 


\subsection{Overlapping common traits}

The first common trait that emerged from the interviewees' responses was a notion we term "open-minded policy." This notion was characterized by open communication, open-door policy, open-mindedness, receptiveness to feedback and criticism, and receptiveness to change. Many respondents highlighted the importance of top managers being open-minded, being open to new stimuli, being aware of opinions, criticism, and feedback from their subordinates, allowing bidirectional communication, and implementing an open-door policy. Some characteristic quotes here were:

- The top management must have the ability to listen and take the distillate of all internal opinions; by listening to people inside the company, sometimes a very big opportunity can be conceived.

- They must be able to listen and accept the fact that their subordinates have opinions and perceptions; they have to allow and accept bottom-up communication; they have to be open to listening to new things; in this way, something new may be created.

The same finding was consistent for middle-level employees. In particular, in the respective part of the interviews, several interviewees described the ideal middle-level employee as an open-minded spirit who is open to new ideas, willing to learn, and receptive to both feedback and criticism. For example, some respondents underlined:

- Middle-level employees have to implement a policy of open doors; they have to be open to new ideas and, similarly to the top management, they have to listen to their subordinates; they have to provide freedom for others to express their ideas; 
often something good results from simple employees; you have to listen, you don't know everything.

- Your antennas must be constantly open; in this way you will obtain the right perception of reality; if you don't, you will have prejudices and misleading obsessions that will make you outdated and obsolete.

Therefore, we formulate the following research proposition:

Research Proposition 1: Top management's and middle management's open-minded policy is positively related to market-driving strategy.

This first proposition delineates that both top and middle-management teams can enhance the emergence of creative behaviors and innovative ideas by listening to the voices of lowerlevel employees. It also implies the pitfalls of narrow-minded, egocentric managers who very often have detrimental thought worlds and mental representations of marketplace conditions. Here, it surfaces for the first time in the literature that changing a market often presupposes changing the organization and synthesizing all internal opinions.

The second trait that appeared to have overlapping significance for both top and middle levels was transformational leadership. Most of the interviewees underscored the importance of top managers developing superior leadership skills, inducing transformations, demonstrating charisma, and inspiring their subordinates instead of merely compensating them:

- For sure, leadership is a big part of a market-driving firm, giving direction to everyone; employees must be inspired to go somewhere; a simple reward or punishment is not sufficient; the leader must give the example, guide, and inspire the employees. 
- The top management must have corporate values and all elements of a transformational leader; they have to lead by example and inspire respect; when you inspire, people follow you, they believe in your decision, and they work hard for its implementation.

The same trait gained noteworthy support for the middle-management level as well. Again, some of the respondents highlighted that middle-level employees must be characterized by corresponding transformational leadership skills in order to inspire lower-level employees and stimulate them to follow the firm's vision voluntarily:

- A market-driving firm ideally has people with leadership skills in all organizational levels; middle-level employees, similarly to the top management, must have a leadership profile in order to convey the market-driving culture from the top management to the lower-level employees; they have to motivate them, convey the vision, lead the way, and show the desired direction.

- According to my thinking, there are doers and leaders. You cannot just simply be a doer in such strategy. You've got to have the strength to make a decision, not be afraid, and manage your group. As top management treats middle management, that's exactly how middle management should treat lower hierarchical levels.

Thus, we formulate the following proposition:

Research Proposition 2: Top management's and middle management's transformational leadership skills are positively related to market-driving strategy.

This second proposition underlines that, given the innovative and creative traits of market-driving organizations and the corresponding attributes of their personnel, transformational leadership is the only form of leadership that can lead to satisfied, empowered, 
and truly fulfilled employees. This can subsequently cultivate learning, commitment, creativity, innovation, and success for the firm (Gumusluoglu \& Ilsev, 2009). This proposition is also the very first in the field to empirically verify the conceptual work of Carrillat et al. (2004).

The final characteristic that appeared to have equal weight and significance for both top and middle managers was creativity. With regard to the top management team, many interviewees acknowledged the importance of top managers fostering creativity throughout the organization and giving the necessary space for all employees to engage in unconventional approaches and the creation of novel and original ideas. Some illuminating quotes here include the following:

- Given that you want to break the rules of the game and discover new ways of approaching and satisfying customers, you have to be creative and create new ideas; you have to think differently.

- The leader must promote creativity; if not, the firm stays static, stops evolving, and fails to create something new. Creativity creates innovation and new things; for example, we try to be creative in our branding strategy, we implement nonbrand-safe practices in an effort to become a cool brand. Our competitors don't, and in this way, consumers come close to us, because we are close to customers.

In harmony with the views expressed about top management, the same trait evoked strong support from many respondents for middle-level employees; their ability to be creative and to develop unconventional approaches to their everyday duties was deemed a factor of high importance for market drivers. In the words of some interviewees:

- Without creativity, employees will never offer anything new; they will remain on conventional paths; therefore, the way they address their market will remain the same. 
- In order to successfully implement a market-driving strategy, the whole firm has to be creative; therefore, employees that offer ideas for the firm's innovativeness are an important element; creativity also favors the change that this strategy demands.

Along such lines, we formulate the following proposition:

Research Proposition 3: Top management's fostering creativity and middle management's creativity skills are positively related to market-driving strategy.

This third proposition empirically endorses the theoretical premises of Kumar, Scheer, and Kotler (2000) for the first time. When employees perform creatively, they suggest novel products, ideas, or procedures that can stimulate the organization's success (Oldham \& Cummings, 1996). However, it is the consistency of approval of creativity from all organizational levels that makes creativity a cornerstone and a significant virtue for market drivers, a claim empirically confirmed by this research proposition.

\subsection{Top management's traits}

Closely following the respondents' answers, it appears that certain characteristics of top management emerge as highly important for the top hierarchical levels, but are not equally important for the middle hierarchical levels. These traits outline the different roles top managers have to play in contrast to middle-level employees.

In this section, the first favorable answering pattern was related to the concept of strong corporate vision, which gained support from respondents in both the aided and unaided sections of the interviews. More precisely, several interviewees pinpointed the importance of top managers having and conveying a strong, clear, and innovative vision that guides the whole organization and keeps organizational members aligned. As some respondents explained: 
- Top management must have a missionary sense; something like "I have something in my mind, a mission that is extremely important; something that surpasses me, that is going to change my life and other peoples' lives; it fascinates me, it mesmerizes me, and I want to pursue it."

- The vision is extremely important because it urges employees to move toward the same direction; it is inspirational. Employees feel they have a higher objective they try to accomplish. It gives meaning to their jobs; they feel they are resolving important problems for their industry or society.

In this regard, we formulate the following research proposition:

Research Proposition 4: Top management's strong corporate vision is positively related to market-driving strategy.

This fourth proposition asserts that a strong corporate vision can guide the market-driving organization's destiny, trigger creative strategies, and change corporate cultures (El-Namaki, 1992). This means that in market drivers it is crucial for top managers to crystalize and endorse visions that are realistic, feasible, clear, challenging, and translatable into goals. This finding confirms both empirically and theoretically the practical examples of several market-driving firms, developed around strong corporate visions of their leading teams (among others, Apple, Tesla, and Amazon).

Strategic management of human resources was also mentioned by many interviewees as of central importance to top managers. Several answers underscored the importance of being anthropocentric, of effectively managing other employees, and of regarding them as a resource through which the market-driving firm can derive and implement innovation. For example, some respondents stated: 
- What top managers have achieved in our firm is that they have been employees themselves; they have started from very low. They hate the term "boss," and they know how to treat an employee in terms of rewards and overall confrontation. One of our founders has a motto: In a time where everybody talks about evaluations, profits, and money, the most crucial factor is the fun factor; to create a firm where people have fun.

- Top managers must realize that, for the type of personnel market drivers attract, maybe things beyond the customary are involved; for example, a sales bonus may not fulfill an employee in such a profile.

In light of these arguments, we formulate the following proposition:

Research Proposition 5: Top management's strategic human resource management practices are positively related to market-driving strategy.

This fifth proposition explicates the importance of developing appropriate human resource policies that are consistent with organizational strategy. These policies significantly drive performance, while develop synergies with traditional market-oriented behaviors (Harris, \& Ogbonna, 2001). Therefore, such practices are fundamental for both marker-driving and marketdriven firms. As a result, this finding empirically affirms the theoretical notion that market-driven and market-driving strategies have a subset of antecedents in common (Neuenburg, 2010). This means that market-driving strategy starts from inside the firm, and this trait comprises an " $\mathrm{X}$ factor" for firms aspiring to shape their markets.

The final response pattern in this section encompassed the importance of top management's prediction skills and insightfulness. A certain body of respondents stressed the importance of forward sensing, predicting future tendencies and outcomes, and being 
perspicacious, in order to identify gaps in the market and avoid pitfalls. For example, some interviewees argued:

- The top management must be forward sensing while looking back at the same time. It has to be insightful and look forward, but refrain from believing that past practices axiomatically will continue to lead to success in the future. It has to stay constantly vigilant.

- The top management must have insight in the industry they want to change; they must look far away and not be interested in short-term success, or success during their own tenure alone.

Based on the foregoing evidence, we formulate the following research proposition:

Research Proposition 6: Top management's prediction skills and insightfulness are positively related to market-driving strategy.

This sixth proposition delineates the importance of the top management's abilities in being able to make predictions and provide guidance through insightful and alert behaviors. If top managers do not accurately predict market tendencies, lag in following the evolution of the industry, or overestimate their firms' abilities, then they lose alignment with the market's needs, with catastrophic results for the organization. This is a proposition that has not been identified in the literature so far. Given that market drivers usually operate in highly turbulent and competitive environments, prediction skills can help them exploit opportunities, make the right strategic maneuvers and sustain competitive advantage over time.

\subsection{Middle management's traits}


Moving on to the middle-level employees, per respondents' answers it was clear that certain traits had higher importance for the middle hierarchical levels and lower weight for the top hierarchical levels. These traits described the different roles middle-level employees have to play in relation to their superiors.

First, middle-level employees' expertise (i.e., a combination of knowledge, experience, and strong educational background) appears to play a crucial role for market-driving firms. Several responses described the importance of having expert middle managers in every working role in order to drive organizational performance. For example, some respondents asserted:

- Market-driving firms cannot afford not to have experts in every field with strong professional backgrounds in order to comprehend the reality that surrounds them.

- They must have strong expertise, namely a combination of experience and knowledge. They have to be trained individuals with competencies and perfect knowledge of their specialization. They must be experts with an encyclopedic perception of an open and contemporary world.

Based on these findings, we formulate the following proposition:

Research Proposition 7: Middle-level employees' expertise is positively related to marketdriving strategy.

This seventh proposition stresses that, in market drivers, expertise is crucial for middle organizational levels. However, what is interesting in this finding is that it is not a necessary condition for top levels. Listening to the voice of lower levels and making well-aimed strategic choices are the primary skills top managers need. In contrast, middle-level employees have to be experts, and they constitute the driving force that will lead the organization toward excellence 
and market dominance. Hence, market drivers have to employ experts in all middle-level specializations.

The next noteworthy response pattern in this section was relevant to the notion of organizational commitment. Several interviewees stressed the importance of middle-level employees having strong emotional bonds with the firm and the firm's purpose, as well as with its management team. As some respondents explained:

- I believe there has to be devotion and commitment. Middle-level employees have to derive love from what they do; they have to believe in what they do and follow this strategy and this new direction. If they don't believe it themselves, they won't convey it to the others.

- It is extremely important to have people that are united and believe in their firm and in its people. It is definitely a precondition to this strategy. You need spontaneous commitment, not enforcement and punishment. Commitment demands believing in something. If you don't believe in something, the chances to do it efficiently are limited.

- You must love the product of your firm. You must love what it produces; what you work for. You must be committed to the organization in general; you must be emotionally attached and passionate about the firm, its purpose, and its products.

On the basis of the abovementioned, we formulate the following proposition:

Research Proposition 8: Middle-level employees' organizational commitment is positively related to market-driving strategy.

From this eighth proposition, given that reactive market orientation and organizational commitment are closely related (Siguaw, Brown, \& Widing, 1994), it appears for the first time in 
the literature that organizational commitment has equal importance for the market-driving facet of market orientation. Therefore, the overall essence of this proposition is that employees' senses of commitment, pride, worthwhile contribution, and belonging can be drivers of superior performance and dominance over competitors.

Intrapreneurship was another characteristic that gained striking support from many respondents. Several interviewees indicated the importance of having employees who engage in entrepreneurial behaviors within the context of the existing firm and who operate as if the firm belonged to them, thus obtaining ownership of their activities. Some insightful quotes here were as follows:

- This trait is extremely important in order to have employees that can make a difference. The employee who acts as an entrepreneur within the firm is probably the one who will generate the extra idea, will open a new road, a new direction, or will be more willing to follow the idea that leads to a market-driving strategy.

- If an employee can break the "chains" that separate the manager from the entrepreneur and think as if he/she was the owner, this will facilitate the marketdriving strategy. This trait governs the culture of our firm; to be a small entrepreneur in your own field; this unifies all the other functions, increases your commitment, and gives you ownership of the firm's purpose.

Based on the foregoing, we formulate the following proposition:

Research Proposition 9: Middle-level employees' intrapreneurship is positively related to market-driving strategy.

This ninth proposition exemplifies the driving force of middle-level employees in developing new ventures within an existing organization as well as in exploiting new 
opportunities. While it is known that intrapreneurship helps managers to renew and revitalize their businesses, to innovate, and to enhance overall business performance (Parker, 2011), this is the first study to identify intrapreneurship's importance at the level of the individual employee, within a market-driving context. This means that individual intrapreneurship will trigger organizational intrapreneurship and enhance the entrepreneurial market-driving culture. This proposition is also the very first to confirm and expand the works of Schindehutte, Morris, and Kocak (2008), Zortea-Johnston, Darroch, and Matear (2012), and Chen et al. (2012).

Middle managers' flexibility was the last noteworthy theme raised by respondents. Flexibility was regarded as an important trait that enables middle-level employees to adjust to frequently unidentified, complex, and volatile working conditions. For instance, some of the interviewees underlined:

- Employees working in a market-driving firm work with differentiated business models and with circumstances they probably face for the first time. Many things in market-driving firms are constantly new (e.g., new products, new communications, new channels); therefore, flexibility is definitely needed.

- A strategy that changes the market also changes the employees; therefore, employees must be flexible and have to be ready to receive the needed change. If employees are not flexible, they comprise a brake and a "weight" in the firm's effort to move fast and to drive its market.

Therefore, our final research proposition is:

Research Proposition 10: Middle-level employees'flexibility is positively related to marketdriving strategy. 
This tenth and final proposition empirically verifies for the first time the conceptual suggestion put forth by Johnson, Lee, Saini, and Grohmann (2003) pertaining to the interrelations of flexibility with the market-driving concept. It is extremely interesting that middle-level employees' flexibility is considered more important as a skill compared to that of adaptability, a point not clarified in the literature so far. Flexibility is the ability to respond successfully to usually short-term challenges, activities, and circumstances, while adaptability is a broader concept referring to the ways that organizations and workers mutually adjust to each other's changing needs to benefit both the individuals and the institution (Myers, Gailliard, \& Putnam, 2013). This means that in market drivers the most important emphasis is on short-term, day-to-day challenges rather than on long-term undertakings.

\section{Discussion and conclusions}

\subsection{Theoretical implications}

Given the importance of market-driving strategy in the contemporary competitive arena, the primary aim of our study was to investigate one of this strategy's most important determinants—namely, personnel attributes. Therefore, we focused on top management's and middle-level employees' role in formulating such a strategy by identifying their most impactful characteristics. By synthesizing findings from all sections, certain intriguing implications for the academic world are developed. In particular, our results support the assertion that, on the one hand, top and middle managers have some prominent overlapping characteristics in common, while on the other hand, their roles have some traits that vary in significance.

First, it appears that concepts such as open-minded policy, transformational leadership, and creativity are of "universal" importance for market drivers, spanning across organizational 
levels. Being open-minded and listening to the voices of subordinates, inspiring subordinates, demonstrating charisma, and encouraging creative and original behaviors are dimensions that act as cornerstones for market-driving firms, independent of the organizational level. These findings are consistent with the theoretical works of Kumar et al. (2000) and Carrillat et al. (2004), who were the first to conceptually point out the importance of creativity and transformational leadership for the market-driving approach. Nevertheless, not only have these suggestions never been tested, this is the first time that they have been empirically confirmed.

In light of these commonalities, however, certain traits appear to have varying importance for top versus middle-level, which points to the different roles managers have to play. First, top managers are mainly responsible for forming, supporting, and transferring a strong corporate vision that will guide the market-driving firm throughout its strategic effort. Second, they have to properly manage human resources and ensure that all employees are supported, satisfied, and aligned with the firm's strategy. Third, top managers have to demonstrate skills of prediction and to be highly insightful; they have to use their experience to weigh up all strategic choices and predict possible outcomes in order to take advantage of opportunities and avoid pitfalls.

With regard to middle-level employees, first, they have to be experts in their field. Their superior knowledge and specialized experience is essential in order to drive the firm's overall performance. In addition, they have to engage in intrapreneurial activities, as if they were the firm owners, and operate with proactiveness, openness to risk, and innovativeness. This finding extends the work of Zortea-Johnston et al. (2012), as well as that of Chen et al. (2012), who linked market-driving strategy with entrepreneurship. However, this is the first time that intrapreneurship is narrowed down in terms of its importance at the individual level. In addition, being committed to their organization, to the firm's purpose, and to the firm's people is of central 
importance for middle-level employees, since in such cases they will be more motivated toward and supportive of the market-driving idea. Furthermore, flexibility is a crucial trait that can assist middle managers to meet the challenges of competing in highly turbulent environments in which market drivers usually operate. Flexibility is a prerequisite for effectively adjusting to new business models, new ventures, and revolutionary ways of addressing the market. This finding is aligned with the theoretical work of Johnson et al. (2003), who conceptually linked marketdriving strategy with strategic flexibility. Nonetheless, it is here empirically confirmed for the first time. Finally, given the importance of the abovementioned concepts for market-driven firms, this study contributes to the literature by providing for the first time evidence affirming the theoretical notion of Neuenburg (2010) that market-driven and market-driving strategies have at least a subset of antecedents in common.

\subsection{Managerial implications}

Our findings carry important managerial implications. In particular, managers must be aware that sometimes it is not enough to simply react to market conditions. On the contrary, leading the market to new avenues can be key to obtaining a paramount competitive position.

Toward this end, managers who wish to drive their industries are strongly advised to develop an open-minded policy and way of thinking; to articulate, endorse, and convey a strong corporate vision; to strategically manage the firm's human resources; to demonstrate charismatic transformational leadership skills; to be able to make predictions and to be insightful; and to foster the development of creative behaviors throughout the organization. Moreover, it is imperative for managers to hire, train, retain, and reinforce middle-level employees who are experts in their specialization, who implement open-minded policies in their everyday routines, 
and who behave as transformational leaders by inspiring their subordinates. Finally, managers are advised to provide the necessary space in order to develop not merely good, but also committed employees; as well as cultivate latent entrepreneurs within the organization who engage in creative and flexible behaviors.

\subsection{Limitations and future research directions}

As with all research, this study is subject to certain boundary conditions and limitations. First, this study is exploratory in nature and should be interpreted as such; thus, its results should be applied to other contexts with caution. In addition, the qualitative nature of the study and the sampling method set certain limits regarding the generalizability of the findings.

Given its limitations, this study aspires to open new avenues for future research. More specifically, future research could explore the role of additional top management and middlelevel employee characteristics, such as personnel skills [e.g., experimentation, speed of action, talent, problem solving, attitudes, as well as employee knowledge (Lado \& Wilson, 1994)]. Moreover, a replication of this study in different countries with various economic growth rates and cultural characteristics and/or with a different research design (e.g., quantitative or mixed) could provide some very valuable insights. Furthermore, investigating the role of other potential antecedent dimensions of market-driving strategy (e.g., organizational capabilities, organizational structure, organizational culture, and organizational systems and processes), as well as relevant moderators, could produce interesting findings. Delving further into the concept of market-driving strategy development, either by comparing its dynamics between flexible startups and large-sized powerful organizations, or by observing it over time through longitudinal data, represents interesting avenues for future research. Moreover, some other 
intriguing research questions are the exact methods that firms use in order to shift from marketdriving to market-driven strategies (and vice versa) and whether firms can successfully implement a combination of these two strategies. Finally, conceptually contrasting marketdriving strategy with existing strategies and related concepts (e.g., blue ocean strategy, disruptive innovation, strategic innovation, and business model innovation) and setting unambiguous boundaries to these comparisons could contribute significantly to the scientific understanding of this domain. 


\section{References}

Angulo-Ruiz, F., Donthu, N., Prior, D., \& Rialp, J. (2014). The financial contribution of customer-oriented marketing capability. Journal of the Academy of Marketing Science, 42(4), 380-399.

Antoncic, B., \& Hisrich, R. D. (2003). Clarifying the intrapreneurship concept. Journal of Small Business and Enterprise Development, 10(1), 7-24.

Bass, B. M. (1990). From transactional to transformational leadership: Learning to share the vision. Organizational Dynamics, 18(3), 19-31.

Bénabou, R., \& Tirole, J. (2002). Self-confidence and personal motivation. The Quarterly Journal of Economics, 117(3), 871-915.

Blut, M., Holzmüller, H. H., \& Stolper, M. (2012). Market shaping orientation and firm performance. In A. Diamantopoulos, W. Fritz, \& L. Hildebrandt (Eds.), Quantitative Marketing and Marketing Management (pp. 447-466). Wiesbaden: Springer Gabler.

Carpenter, G. S., Glazer, R., \& Nakamoto, K. (2001). Market-driving strategies: Toward a new concept of competitive advantage. In. D. Iacobucci (Ed.), Kellogg on Marketing (pp. 103129). New York: John Wiley \& Sons.

Carrillat, F. A., Jaramillo, F., \& Locander, W. B. (2004). Market-driving organizations: A framework. Academy of Marketing Science Review, 5(5), 1-16.

Chen, Y. C., Li, P. C., \& Evans, K. R. (2012). Effects of interaction and entrepreneurial orientation on organizational performance: Insights into market driven and market driving. Industrial Marketing Management, 41(6), 1019-1034.

Creswell, J. W. (2008). Research Design: Qualitative, Quantitative, and mixed methods approaches, 2nd edition. Sage publications.

Dai, L., Maksimov, V., Gilbert, B. A., \& Fernhaber, S. A. (2014). Entrepreneurial orientation and international scope: The differential roles of innovativeness, proactiveness, and risktaking. Journal of Business Venturing, 29(4), 511-524.

Day, G. S. (1994). The capabilities of market-driven organizations. Journal of Marketing, 58(4), $37-52$.

Daymon, C., \& Holloway, I. (2010). Qualitative research methods in public relations and marketing communications. New York: Routledge.

Drucker, P. (1954). The Principles of Management. New York.

Dworkin, S. L. (2012). Sample size policy for qualitative studies using in-depth interviews. Archives of Sexual Behavior, 41(6), 1319-1320.

El-Namaki, M. (1992). Creating a corporate vision. Long Range Planning, 25(6), 25-29.

Ellis, S., Mendel, R., \& Nir, M. (2006). Learning from successful and failed experience: The moderating role of kind of after-event review. Journal of Applied Psychology, 91(3), 669680.

Filieri, R. (2015). From market-driving to market-driven: an analysis of Benetton's strategy change and its implications for long-term performance. Marketing Intelligence \& Planning, 33(3), 238-257.

Flick, U. (2004). Triangulation in qualitative research. In U. Flick, E. Von Kardorff, \& I. Steinke (Eds.), A companion to qualitative research. (pp. 178-183). London, Thousand Oaks, New Delhi: Sage Publications.

Foltean, F., \& Feder, E. S. (2009). Market orientation and international entrepreneurship. Transformations in Business \& Economics, 8(3), 23-43. 
Ghauri, P., Wang, F., Elg, U., \& Rosendo-Ríos, V. (2016). Market driving strategies: Beyond localization. Journal of Business Research, 69(12), 5682-5693.

Graebner, M. E., Martin, J. A., \& Roundy, P. T. (2012). Qualitative data: Cooking without a recipe. Strategic Organization, 10(3), 276-284.

Graziano, W. G., Hair, E. C., \& Finch, J. F. (1997). Competitiveness mediates the link between personality and group performance. Journal of Personality and Social Psychology, 73(6), 1394-1408.

Gulati, R., \& Oldroyd, J. B. (2005). The quest for customer focus. Harvard Business Review, 83(4), 92-101.

Gumusluoglu, L., \& Ilsev, A. (2009). Transformational leadership, creativity, and organizational innovation. Journal of Business Research, 62(4), 461-473.

Harris, L. C., \& Cai, K. Y. (2002). Exploring market driving: A case study of De Beers in China. Journal of Market-Focused Management, 5(3), 171-196.

Harris, L. C., \& Ogbonna, E. (2001). Strategic human resource management, market orientation, and organizational performance. Journal of Business Research, 51(2), 157-166.

Heller, F., Pusic, E., Wilpert, B., \& Strauss, G. (1998). Organizational participation: Myth and reality (Vol. 4). Oxford: Oxford University Press.

Herhausen, D. (2016). Unfolding the ambidextrous effects of proactive and responsive market orientation. Journal of Business Research, 69(7), 2585-2593.

Herman, H. M., \& Mitchell, R. J. (2010). A theoretical model of transformational leadership and knowledge creation: The role of open-mindedness norms and leader-member exchange. Journal of Management \& Organization, 16(1), 83-99.

Hernández-Mogollon, R., Cepeda-Carrión, G., Cegarra-Navarro, J. G., \& Leal-Millán, A. (2010). The role of cultural barriers in the relationship between open-mindedness and organizational innovation. Journal of Organizational Change Management, 23(4), 360376.

Hills, S. B., \& Sarin, S. (2003). From market driven to market driving: An alternate paradigm for marketing in high technology industries. Journal of Marketing Theory and Practice, 11(3), 13-24.

Houston, J. M., Farese, D. M., \& La Du, T. J. (1992). Assessing competitiveness: A validation study of the competitiveness index. Personality and Individual Differences, 13(10), 1153-1156.

Iles, P., Forster, A., \& Tinline, G. (1996). The changing relationships between work commitment, personal flexibility and employability: An evaluation of a field experiment in executive development. Journal of Managerial Psychology, 11(8), 18-34.

Jaworski, B., Kohli, A. K., \& Sahay, A. (2000). Market-driven versus driving markets. Journal of the Academy of Marketing Science, 28(1), 45-54.

Jaworski, B. J., \& Kohli, A. K. (1993). Market orientation: Antecedents and consequences. The Journal of Marketing, 7(3), 53-70.

Johnson, J. L., Lee, R. P. W., Saini, A., \& Grohmann, B. (2003). Market-focused strategic flexibility: Conceptual advances and an integrative model. Journal of the Academy of Marketing Science, 31(1), 74-89.

Kirca, A. H., Jayachandran, S., \& Bearden, W. O. (2005). Market orientation: A meta-analytic review and assessment of its antecedents and impact on performance. Journal of Marketing, 69(2), 24-41. 
Kohli, A. K., \& Jaworski, B. J. (1990). Market orientation: The construct, research propositions, and managerial implications. The Journal of Marketing, 54(2), 1-18.

Krippendorff, K. (2004). Content analysis: An introduction to its methodology. Thousand Oaks, London, New Delhi: Sage Publications.

$\mathrm{Ku}$, Y. C., Wei, C. P., \& Hsiao, H. W. (2012). To whom should I listen? Finding reputable reviewers in opinion-sharing communities. Decision Support Systems, 53(3), 534-542.

Kumar, N., Scheer, L., \& Kotler, P. (2000). From market driven to market driving. European Management Journal, 18(2), 129-142.

Lado, A. A., \& Wilson, M. C. (1994). Human resource systems and sustained competitive advantage: A competency-based perspective. Academy of Management Review, 19(4), 699-727.

Lam, S. S., Chen, X. P., \& Schaubroeck, J. (2002). Participative decision making and employee performance in different cultures: The moderating effects of allocentrism/idiocentrism and efficacy. Academy of Management Journal, 45(5), 905-914.

Lancaster, G., \& Van Der Velden, H. (2004). The influence of employee characteristics on market orientation. International Journal of Bank Marketing, 22(5), 343-365.

Locander, W. B., \& Hermann, P. W. (1979). The effect of self-confidence and anxiety on information seeking in consumer risk reduction. Journal of Marketing Research, 16(2), 268-274.

MacKenzie, S. B., Podsakoff, P. M., \& Rich, G. A. (2001). Transformational and transactional leadership and salesperson performance. Journal of the Academy of Marketing Science, 29(2), 115-134.

Mason, J. (2002). Qualitative researching. London: Sage Publications.

Matsaganis, M. (2011). The welfare state and the crisis: the case of Greece. Journal of European Social Policy, 21(5), 501-512.

Meyer, J. P., \& Herscovitch, L. (2001). Commitment in the workplace: Toward a general model. Human Resource Management Review, 11(3), 299-326.

Miles, M. B., \& Huberman, A. M. (1994). Qualitative data analysis: An expanded sourcebook. Thousand Oaks, London, New Delhi: Sage Publications.

Miller, D., \& Friesen, P. H. (1978). Archetypes of strategy formulation. Management Science, 24(9), 921-933.

Morse, J. M. (1991). Approaches to qualitative-quantitative methodological triangulation. Nursing research, 40(2), 120-123.

Mowday, R. T., Steers, R. M., \& Porter, L. W. (1979). The measurement of organizational commitment. Journal of Vocational Behavior, 14(2), 224-247.

Myers, K. K., Gailliard, B. M., \& Putnam, L. L. (2013). Reconsidering the concept of workplace flexibility: Is adaptability a better solution?. Annals of the International Communication Association, 36(1), 195-230.

Najafi-Tavani, S., Sharifi, H., \& Najafi-Tavani, Z. (2016). Market orientation, marketing capability, and new product performance: The moderating role of absorptive capacity. Journal of Business Research, 69(11), 5059-5064.

Narver, J. C., Slater, S. F., \& MacLachlan, D. L. (2004). Responsive and proactive market orientation and new-product success. Journal of Product Innovation Management, 21(5), 334-347. 
Neuenburg, J. P. (2010). Market-driving behavior in emerging firms: A study on market-driving behavior, its moderators and performance implications in German emerging technology ventures. Wiesbaden: Springer Gabler.

Neuendorf, K. A. (2002). The content analysis guidebook. Thousand Oaks, London, New Delhi: Sage Publications.

Nijstad, B. A., \& Stroebe, W. (2006). How the group affects the mind: A cognitive model of idea generation in groups. Personality and Social Psychology Review, 10(3), 186-213.

Oldham, G. R., \& Cummings, A. (1996). Employee creativity: Personal and contextual factors at work. Academy of Management Journal, 39(3), 607-634.

Parasuraman, A., Grewal, D., \& Krishnan, R. (2004). Marketing research. Boston, New York: Houghton Mifflin Company.

Paridon, T. J. (2004). Retail opinion sharing: Conceptualization and measurement. Journal of Retailing and Consumer Services, 11(2), 87-93.

Parker, S. C. (2011). Intrapreneurship or entrepreneurship?. Journal of Business Venturing, 26(1), 19-34.

Parkhurst, H. B. (1999). Confusion, lack of consensus, and the definition of creativity as a construct. The Journal of Creative Behavior, 33(1), 1-21.

Pfeffer, J. (1995). Competitive advantage through people: Unleashing the power of the work force. Boston: Harvard Business School Press.

Ployhart, R. E., \& Bliese, P. D. (2006). Individual adaptability (I-ADAPT) theory: Conceptualizing the antecedents, consequences, and measurement of individual differences in adaptability. In C.S. Burke, L.G. Pierce, \& E. Salas (Eds.), Understanding adaptability: A prerequisite for effective performance within complex environments (pp. 3-39). Oxford, United Kingdom: Elsevier

Popping, R. (1988). On agreement indices for nominal data. In W.E. Saris, \& I.N. Gallhofer (Eds.) Sociometric research (pp. 90-105). United Kingdom: Palgrave Macmillan.

Pratt, M. G. (2009). From the editors: For the lack of a boilerplate: Tips on writing up (and reviewing) qualitative research. Academy of Management Journal, 52(5), 856-862.

Raju, P., Lonial, S. C., \& Crum, M. D. (2011). Market orientation in the context of SMEs: A conceptual framework. Journal of Business Research, 64(12), 1320-1326.

Rowley, J. (2012). Conducting research interviews. Management Research Review, 35(3/4), 260-271.

Schindehutte, M., Morris, M. H., \& Kocak, A. (2008). Understanding market-driving behavior: The role of entrepreneurship. Journal of Small Business Management, 46(1), 4-26.

Schreier, M. (2012). Qualitative content analysis in practice. London, Thousand Oaks, New Delhi, Singapore: Sage Publications.

Schreier, M. (2014). Qualitative content analysis. In U. Flick (Ed.) The SAGE handbook of qualitative data analysis (pp. 170-183). London, Thousand Oaks, New Delhi, Singapore: Sage Publications.

Selden, L., \& MacMillan, I. C. (2006). Manage customer-centric innovation-systematically. Harvard Business Review, 84(4), 108-116.

Shah, D., Rust, R. T., Parasuraman, A., Staelin, R., \& Day, G. S. (2006). The path to customer centricity. Journal of Service Research, 9(2), 113-124.

Siegel, H. (2009). Open-mindedness, critical thinking, and indoctrination: Homage to William Hare. Philosophical Inquiry in Education, 18(1), 26-34. 
Siguaw, J. A., Brown, G., \& Widing, R. E. (1994). The influence of the market orientation of the firm on sales force behavior and attitudes. Journal of Marketing Research, 31(1), 106116.

Stankov, L., \& Crawford, J. D. (1997). Self-confidence and performance on tests of cognitive abilities. Intelligence, 25(2), 93-109.

Steers, R. M. (1977). Antecedents and outcomes of organizational commitment. Administrative Science Quarterly, 22(1), 46-56.

Storbacka, K., \& Nenonen, S. (2015). Learning with the market: Facilitating market innovation. Industrial Marketing Management, 44, 73-82.

Strauss, A., \& Corbin, J. (1998). Basics of qualitative research: Techniques and procedures for developing grounded theory. Thousand Oaks: Sage Publications.

Tarnovskaya, V., Elg, U., \& Burt, S. (2008). The role of corporate branding in a market driving strategy. International Journal of Retail \& Distribution Management, 36(11), 941-965.

Thurmond, V. A. (2001). The point of triangulation. Journal of Nursing Scholarship, 33(3), 253258.

Toubia, O. (2006). Idea generation, creativity, and incentives. Marketing Science, 25(5), 411425.

Urde, M., Baumgarth, C., \& Merrilees, B. (2013). Brand orientation and market orientationFrom alternatives to synergy. Journal of Business Research, 66(1), 13-20.

Van Dam, K., Oreg, S., \& Michel, A. (2013). Employee adaptability to change at work: A multidimensional, resource-based framework. In S. Oreg, A. Michel, \& R.T. By, (Eds.). The psychology of organizational change: Viewing change from the employee's perspective (pp. 123-142). New York: Cambridge University Press.

Van Vuuren, J., \& Wörgötter, N. (2013). Market driving behaviour in organisations: Antecedents and outcomes. South African Journal of Economic and Management Sciences, 16(2), $115-141$.

Weinzimmer, L. G., \& Esken, C. A. (2017). Learning from mistakes: How mistake tolerance positively affects organizational learning and performance. The Journal of Applied Behavioral Science, 53(3), 322-348.

Zavras, D., Tsiantou, V., Pavi, E., Mylona, K., \& Kyriopoulos, J. (2012). Impact of economic crisis and other demographic and socio-economic factors on self-rated health in Greece. The European Journal of Public Health, 23(2), 206-210.

Zhou, K. Z., Brown, J. R., \& Dev, C. S. (2009). Market orientation, competitive advantage, and performance: A demand-based perspective. Journal of Business Research, 62(11), 10631070.

Zortea-Johnston, E., Darroch, J., \& Matear, S. (2012). Business orientations and innovation in small and medium sized enterprises. International Entrepreneurship and Management Journal, 8(2), 145-164. 


\section{Table 1: Investigating 10 characteristics of top management}

\begin{tabular}{|c|c|c|c|}
\hline Concept & Definition & $\begin{array}{c}\text { Relevance to } \\
\text { Market-Driving Strategy }\end{array}$ & Sources \\
\hline $\begin{array}{l}\text { (1) Transformational } \\
\text { Leadership }\end{array}$ & $\begin{array}{l}\text { Type of leadership in which the leader, beyond merely } \\
\text { administering rewards and punishments, demonstrates } \\
\text { charisma, inspires organizational members, and provides } \\
\text { intellectual stimulation and individualized consideration. }\end{array}$ & $\begin{array}{l}\text { Has been theoretically stressed as the most appropriate leadership type that } \\
\text { fosters a market-driving culture. Conveys the market-driving vision, } \\
\text { stimulates employees' creativity, and impacts innovative capacity. }\end{array}$ & $\begin{array}{l}\text { Bass (1990) } \\
\text { MacKenzie, Podsakoff, \& Rich (2001) } \\
\text { Carrillat et al. (2004) }\end{array}$ \\
\hline (2) Fostering Creativity & $\begin{array}{l}\text { The ability displayed when developing novel solutions to } \\
\text { existing problems. }\end{array}$ & $\begin{array}{l}\text { Reexamines work assumptions, improves performance, and leads to } \\
\text { breakthrough innovations that reshape business systems. Furthermore, it } \\
\text { improves the value proposition. }\end{array}$ & $\begin{array}{l}\text { Parkhurst (1999) } \\
\text { Kumar et al. (2000) } \\
\text { Carrillat et al. (2004) } \\
\end{array}$ \\
\hline $\begin{array}{l}\text { (3) Fostering Open- } \\
\text { Mindedness }\end{array}$ & $\begin{array}{l}\text { A trait that qualifies a person's activities in thinking; i.e., } \\
\text { his/her ability and willingness to form and revise his/her } \\
\text { views in light of evidence and argumentation. }\end{array}$ & $\begin{array}{l}\text { Associated with unlearning, proactively questions existing organizational } \\
\text { routines, modifies organizational assumptions, and facilitates } \\
\text { organizational innovation. Generates out-of-the-box ideas that can be } \\
\text { sources of market-driving ideas. }\end{array}$ & $\begin{array}{l}\text { Siegel (2009) } \\
\text { Hernández-Mogollon, Cepeda-Carrión, } \\
\text { Cegarra-Navarro, \& Leal-Millán } \\
(2010)\end{array}$ \\
\hline $\begin{array}{l}\text { (4) Fostering Freedom } \\
\text { of Opinion-Sharing }\end{array}$ & $\begin{array}{l}\text { Open exchange of personal opinions and useful } \\
\text { information regarding a subject of interest. }\end{array}$ & $\begin{array}{l}\text { Fosters dialogue, triggers novel idea generation, stimulates polyphony, } \\
\text { generates synergies, and improves teamwork, concepts highly necessary } \\
\text { for market-driving firms. }\end{array}$ & $\begin{array}{l}\mathrm{Ku}, \text { Wei, \& Hsiao (2012) } \\
\text { Paridon (2004) }\end{array}$ \\
\hline $\begin{array}{l}\text { (5) Fostering Risk- } \\
\text { Taking }\end{array}$ & $\begin{array}{l}\text { The degree to which managers are willing to make large } \\
\text { and risky resource commitments (i.e., those that have a } \\
\text { reasonable chance of costly failure). }\end{array}$ & $\begin{array}{l}\text { Associated with a tendency to be optimistic and perceive opportunities. } \\
\text { Triggers performance. Fosters entrepreneurial cultures in market-driving } \\
\text { firms that operate in turbulent environments, where risk and failure are } \\
\text { possible outcomes. }\end{array}$ & $\begin{array}{l}\text { Miller \& Friesen (1978) } \\
\text { Dai, Maksimov, Gilbert, \& Fernhaber } \\
\text { (2014) }\end{array}$ \\
\hline $\begin{array}{l}\text { (6) Fostering New Idea } \\
\text { Generation }\end{array}$ & $\begin{array}{l}\text { One of the first stages of problem solving or decision- } \\
\text { making, in which potential solutions, decision alternatives, } \\
\text { or hypotheses are generated. Involves creating new } \\
\text { concepts, plans, and themes. }\end{array}$ & $\begin{array}{l}\text { Relates to creativity and is critical to (1) new product development, (2) } \\
\text { marketing strategy, and ( } 3 \text { ) marketing activities. Market-driving firms } \\
\text { ground their success on innovative ideas that allow them to preempt } \\
\text { competition. }\end{array}$ & $\begin{array}{l}\text { Nijstad \& Stroebe (2006) } \\
\text { Toubia (2006) }\end{array}$ \\
\hline (7) Tolerating Mistakes & $\begin{array}{l}\text { The conditions within an organization that allow } \\
\text { organizational members to take risks and pursue innovative } \\
\text { solutions without the fear of repercussions for making } \\
\text { mistakes. }\end{array}$ & $\begin{array}{l}\text { Improves knowledge, leads to intelligent risk-taking, increases } \\
\text { performance, enhances exploration learning, and triggers critical thought, } \\
\text { concepts highly relevant for market-driving strategy. }\end{array}$ & $\begin{array}{l}\text { Weinzimmer \& Esken (2017) } \\
\text { Ellis, Mendel, \& Nir (2006) } \\
\text { Chen et al. (2012) }\end{array}$ \\
\hline $\begin{array}{l}\text { (8) Having Strong } \\
\text { Corporate Vision }\end{array}$ & $\begin{array}{l}\text { A mental perception of the kind of environment an } \\
\text { individual or organization aspires to create within a broad } \\
\text { time horizon. }\end{array}$ & $\begin{array}{l}\text { Relates to proactive management. Results in offerings that reveal new } \\
\text { consumer needs. Gives orientation to employees. Develops the market- } \\
\text { driving firms' activities around their top management teams' inspirations. }\end{array}$ & $\begin{array}{l}\text { El-Namaki (1992) } \\
\text { Blut, Holzmüller, \& Stolper (2012) } \\
\text { Carrillat et al. (2004) }\end{array}$ \\
\hline $\begin{array}{l}\text { (9) Encouraging } \\
\text { Participative Decision- } \\
\text { Making }\end{array}$ & $\begin{array}{l}\text { The totality of ways in which individuals, groups, or } \\
\text { collectives contribute to the choice process through self- } \\
\text { determined choices among possible actions during the } \\
\text { decision process. }\end{array}$ & $\begin{array}{l}\text { Reinforces employees' commitment, enhances task performance, triggers } \\
\text { job satisfaction, reduces turnover, and increases the employees' } \\
\text { supportiveness toward the market-driving idea. }\end{array}$ & $\begin{array}{l}\text { Heller, Pusic, Wilpert, \& Strauss } \\
\text { (1998) } \\
\text { Lam, Chen, \& Schaubroeck (2002) }\end{array}$ \\
\hline $\begin{array}{l}\text { (10) Keeping Locus of } \\
\text { Decision-Making Close } \\
\text { to Customers }\end{array}$ & $\begin{array}{l}\text { Empowering front-line employees who interact with } \\
\text { customers, in an effort to take advantage of available } \\
\text { customer information. }\end{array}$ & $\begin{array}{l}\text { Creates a customer-centric organization. Develops a thorough } \\
\text { understanding of current market conditions. Analyzes current market } \\
\text { information, identifies relevant gaps and opportunities, and results in } \\
\text { emergence of subsequent innovative ideas. }\end{array}$ & $\begin{array}{l}\text { Selden \& MacMillan (2006) } \\
\text { Gulati \& Oldroyd (2005) }\end{array}$ \\
\hline
\end{tabular}




\section{Table 2: Investigating 10 characteristics of middle-level employees}

\begin{tabular}{|c|c|c|c|}
\hline Concept & Definition & $\begin{array}{c}\text { Relevance to } \\
\text { Market-Driving Strategy }\end{array}$ & Sources \\
\hline $\begin{array}{l}\text { (1) Transformational } \\
\text { Leadership }\end{array}$ & $\begin{array}{l}\text { Type of leadership in which the leader, beyond merely } \\
\text { administering rewards and punishments, demonstrates } \\
\text { charisma, inspires organizational members, and provides } \\
\text { intellectual stimulation and individualized consideration. }\end{array}$ & $\begin{array}{l}\text { Has been theoretically emphasized as the most appropriate leadership type that can } \\
\text { foster a market-driving culture. Conveys the market-driving vision, stimulates } \\
\text { employees' creativity, and impacts innovative capacity. }\end{array}$ & $\begin{array}{l}\text { Bass (1990) } \\
\text { MacKenzie et al. (2001) } \\
\text { Carrillat et al. (2004) }\end{array}$ \\
\hline (2) Intrapreneurship & $\begin{array}{l}\text { Entrepreneurship within an existing organization via } \\
\text { behaviors that depart from what is considered customary } \\
\text { in order to pursue opportunities. }\end{array}$ & $\begin{array}{l}\text { Creates economic value, increases performance, revitalizes businesses, triggers } \\
\text { innovativeness, and enhances overall performance. }\end{array}$ & $\begin{array}{l}\text { Antoncic \& Hisrich (2003) } \\
\text { Schindehutte et al. (2008) } \\
\text { Zortea-Johnston et al. (2012) } \\
\text { Parker (2011) }\end{array}$ \\
\hline (3) Creativity & $\begin{array}{l}\text { The ability displayed when developing novel solutions } \\
\text { to existing problems. }\end{array}$ & $\begin{array}{l}\text { Reexamines work assumptions, improves performance, leads to breakthrough } \\
\text { innovations that reshape business systems, and improves the value proposition. }\end{array}$ & $\begin{array}{l}\text { Parkhurst (1999) } \\
\text { Kumar et al. (2000) } \\
\text { Carrillat et al. (2004) }\end{array}$ \\
\hline (4) Self-Confidence & $\begin{array}{l}\text { An employee's self-esteem; his/her self-assurance } \\
\text { regarding a decision he/she has to make, such as } \\
\text { performing a specific task or solving a specific problem. }\end{array}$ & $\begin{array}{l}\text { Can be a key to personal success. Enhances individual motivation, personal } \\
\text { satisfaction, and persuasive ability. Makes subordinates feel safe and triggers their } \\
\text { performance. }\end{array}$ & $\begin{array}{l}\text { Locander \& Hermann (1979) } \\
\text { Bénabou \& Tirole (2002) } \\
\text { Stankov \& Crawford (1997) }\end{array}$ \\
\hline (5) Commitment & $\begin{array}{l}\text { A force that binds an individual to a course of action that } \\
\text { is of relevance to a particular target. }\end{array}$ & $\begin{array}{l}\text { Implies a desire and intent to remain, increases attendance, enhances employee } \\
\text { retention, and drives job performance. Makes employees believe in the } \\
\text { organization's goals, exert considerable effort, and desire to maintain membership. } \\
\text { Increases their supportiveness of the market-driving idea. }\end{array}$ & $\begin{array}{l}\text { Meyer \& Herscovitch }(2001) \\
\text { Mowday, Steers, \& Porter } \\
(1979) \\
\text { Steers (1977) }\end{array}$ \\
\hline (6) Risk-Taking & $\begin{array}{l}\text { The degree to which managers are willing to make large } \\
\text { and risky resource commitments (i.e., those that have a } \\
\text { reasonable chance of costly failure). }\end{array}$ & $\begin{array}{l}\text { Is associated with a tendency to be optimistic and perceive opportunities rather than } \\
\text { threats. Can trigger performance. Enhances market-driving firms' entrepreneurial } \\
\text { cultures. Guides their operation in turbulent environments where risk and failure are } \\
\text { possible outcomes. }\end{array}$ & $\begin{array}{l}\text { Miller \& Friesen (1978) } \\
\text { Dai, Maksimov, Gilbert, \& } \\
\text { Fernhaber (2014) }\end{array}$ \\
\hline $\begin{array}{l}\text { (7) Individual } \\
\text { Adaptability }\end{array}$ & $\begin{array}{l}\text { An individual's skill, disposition, willingness, or } \\
\text { motivation to exhibit different task, social, and } \\
\text { environmental features. }\end{array}$ & $\begin{array}{l}\text { Drives effective performance in complex environments. Entails the competency of } \\
\text { successfully adjusting to long-term, changing work contexts. Helps market-driving } \\
\text { firms adapt in competitive, complex, and volatile environments. }\end{array}$ & $\begin{array}{l}\text { Ployhart \& Bliese (2006) } \\
\text { Van Dam, Oreg, \& Michel } \\
\text { (2013) }\end{array}$ \\
\hline (8) Competitiveness & The desire to win in interpersonal situations. & $\begin{array}{l}\text { Mediates the link between personality and group performance. Is related to status } \\
\text { consciousness and increases ambition. Helps market-driving firms to surpass } \\
\text { competition and obtain sustainable competitive advantage. }\end{array}$ & $\begin{array}{l}\text { Houston, Farese, \& La Du } \\
\text { (1992) } \\
\text { Graziano, Hair, \& Finch (1997) }\end{array}$ \\
\hline (9) Flexibility & $\begin{array}{l}\text { The ability to adjust behavior, management, and } \\
\text { leadership styles to a variety of situations and } \\
\text { stakeholder groups. }\end{array}$ & $\begin{array}{l}\text { Expresses the ability to bend to (usually short-term) challenges and conditions. Can } \\
\text { lead market-driving firms to sustainable competitive advantage. Individual } \\
\text { flexibility drives organizational flexibility, career success, and job performance. }\end{array}$ & $\begin{array}{l}\text { Iles, Forster, \& Tinline (1996) } \\
\text { Johnson et al. (2003) }\end{array}$ \\
\hline $\begin{array}{l}\text { (10) Open- } \\
\text { Mindedness }\end{array}$ & $\begin{array}{l}\text { A trait that qualifies a person's activities in thinking; } \\
\text { i.e., his/her ability and willingness to form and revise } \\
\text { his/her views in the light of evidence and argumentation. }\end{array}$ & $\begin{array}{l}\text { Associated with unlearning, proactively questions existing organizational routines, } \\
\text { modifies organizational assumptions, and facilitates organizational innovation. } \\
\text { Generates out-of-the-box ideas that can be sources of market-driving ideas. }\end{array}$ & $\begin{array}{l}\text { Siegel (2009) } \\
\text { Hernández-Mogollon, Cepeda- } \\
\text { Carrión, Cegarra-Navarro, \& } \\
\text { Leal-Millán (2010) }\end{array}$ \\
\hline
\end{tabular}


Table 3: Sample description

\begin{tabular}{|c|c|c|c|}
\hline Number & Sector & Firm Profile & Relationship with Market-Driving Strategy \\
\hline Firm 1 & Commodities & $\begin{array}{l}\text { A large established and powerful } \\
\text { multinational firm with strong } \\
\text { resources. }\end{array}$ & $\begin{array}{l}\text { Has strongly driven the behaviors of the state, the regulators and the multipliers (wider society, } \\
\text { investors, media, etc.) via strategic and integrated communication campaigns, exploiting its } \\
\text { powerful brand name and its influence over the state's economy. }\end{array}$ \\
\hline Firm 3 & Services & A small domestic and flexible firm. & $\begin{array}{l}\text { Has been given awards for successfully driving the behaviors of customers (e.g., tourists) and } \\
\text { multipliers (media, institutions, etc.), by pioneering in the fields of Sports Tourism (enriching } \\
\text { tourist products). }\end{array}$ \\
\hline Firm 4 & Cosmetics & $\begin{array}{l}\text { A large established multinational firm } \\
\text { with strong resources. }\end{array}$ & $\begin{array}{l}\text { Has successfully implemented the market-driving concept (1) at the product level, by investing } \\
\text { in R\&D activities and introducing successful innovative products, thus shaping customer } \\
\text { preferences, and (2) at the distributors' level, by influencing and shaping a network of } \\
6,000,000 \text { distributors in more than } 100 \text { countries. }\end{array}$ \\
\hline Firm 5 & $\begin{array}{l}\text { Foods \& } \\
\text { Beverages }\end{array}$ & $\begin{array}{l}\text { A large established multinational firm } \\
\text { with strong resources; one of the } \\
\text { traditional world leaders in its sector. }\end{array}$ & $\begin{array}{l}\text { At certain points in its history, has driven its markets at the product level by introducing } \\
\text { differentiated products that were a point of reference in its sector, thus driving customers' } \\
\text { preferences and behavior. }\end{array}$ \\
\hline Firm 7 & Services & $\begin{array}{l}\text { A large established multinational } \\
\text { organization with strong resources, one } \\
\text { of the world leaders in its sector. }\end{array}$ & $\begin{array}{l}\text { Is an expert in the field of consulting services with powerful marketplace position. } \\
\text { Continuously develops new approaches for addressing its customers; has heavily invested in } \\
\text { new technologies and developed strategic alliances with partners. }\end{array}$ \\
\hline Firm 8 & Cosmetics & $\begin{array}{l}\text { A large established multinational firm; } \\
\text { one of the world leaders in the sector of } \\
\text { personal care. }\end{array}$ & $\begin{array}{l}\text { Has heavily invested in research and technology innovation (including non-invasive imagery, } \\
\text { robotics, and 3-D modeling). Has introduced numerous innovative products, thus shaping } \\
\text { customers' preferences and becoming a point of reference in its sector. }\end{array}$ \\
\hline Firm 9 & $\begin{array}{l}\text { Technology, e- } \\
\text { commerce }\end{array}$ & $\begin{array}{l}\text { A medium-sized flexible startup firm of } \\
\text { domestic background, with activities in } \\
\text { the wider region of southeastern } \\
\text { Europe. }\end{array}$ & $\begin{array}{l}\text { Has revolutionized the industry of high technology by introducing an innovative search engine } \\
\text { that compares prices. Its unique business model has changed the way consumers purchase } \\
\text { goods, moving from traditional channels to its electronic platform. Has also led to the } \\
\text { development of numerous e-shops operating around its platform. }\end{array}$ \\
\hline Firm 10 & $\begin{array}{l}\text { High } \\
\text { technology, } \\
\text { Online food } \\
\text { delivery }\end{array}$ & $\begin{array}{l}\text { A medium-sized flexible domestic } \\
\text { startup firm with high growth rates. }\end{array}$ & $\begin{array}{l}\text { Has revolutionized the industry of food delivery by introducing an innovative electronic } \\
\text { platform. Its business model has shifted the way consumers purchase delivery food, moving } \\
\text { from traditional ways to the use of its electronic platform. }\end{array}$ \\
\hline
\end{tabular}




\begin{tabular}{|c|c|c|c|}
\hline & $\begin{array}{l}\text { construction, } \\
\text { Manufacturing }\end{array}$ & with strong resources. & $\begin{array}{l}\text { technologies (e.g., smart pumps and facilities, energy efficient solutions, heating, air } \\
\text { conditioning, and water supply). Has subsequently driven the behavior of its industrial clients. }\end{array}$ \\
\hline Firm 12 & $\begin{array}{l}\text { Telecommunica } \\
\text { tions, Energy, } \\
\text { Electrification, } \\
\text { Healthcare, } \\
\text { High } \\
\text { technology, } \\
\text { Services }\end{array}$ & $\begin{array}{l}\text { A large established multinational firm } \\
\text { with strong resources. }\end{array}$ & $\begin{array}{l}\text { Has driven its markets at certain points in its history. Continuously introduces state-of-the-art } \\
\text { technologically advanced products (e.g., integrated automation technologies and 3-D printing); } \\
\text { drives the behavior of the state, regulators and multipliers (e.g., wider society and investors), } \\
\text { exploiting its influence over the state's economy. }\end{array}$ \\
\hline Firm 13 & $\begin{array}{l}\text { High } \\
\text { technology, } \\
\text { Healthcare }\end{array}$ & $\begin{array}{l}\text { A medium-sized flexible domestic } \\
\text { startup firm. }\end{array}$ & $\begin{array}{l}\text { Has revolutionized the industry of healthcare by introducing an innovative digital service. Its } \\
\text { business model has shifted the way patients reach healthcare professionals, moving from } \\
\text { traditional ways to the use of its electronic platform. }\end{array}$ \\
\hline Firm 14 & B-to-B services & $\begin{array}{l}\text { A large established multinational firm } \\
\text { with strong resources; one of the world } \\
\text { leaders in its sector. }\end{array}$ & $\begin{array}{l}\text { Is the market leader in its field and has set its industry's standards. Has developed specialized } \\
\text { and flexible Strategic Business Units in order to offer integrated customized service solutions. } \\
\text { Has assisted its clients to intervene during consumers' evaluation of alternatives at numerous } \\
\text { selling points. }\end{array}$ \\
\hline Firm 15 & $\begin{array}{l}\text { Telecommunica } \\
\text { tions }\end{array}$ & $\begin{array}{l}\text { A large established multinational firm } \\
\text { with strong resources; one of the world } \\
\text { leaders in its sector. }\end{array}$ & $\begin{array}{l}\text { Has heavily invested in technology; has successfully driven its multipliers (e.g., wider society, } \\
\text { investors, and media) via communication campaigns and sponsorships, positioning a powerful } \\
\text { brand image. }\end{array}$ \\
\hline Firm 16 & Services & A medium, domestic and flexible firm. & $\begin{array}{l}\text { Has defined creativity as its core corporate value. Has developed a customer-centric structure } \\
\text { in order to provide customized solutions. Is a pioneer in creating local and international } \\
\text { content. Has driven the behavior of multipliers (e.g. wider society, media and so forth). }\end{array}$ \\
\hline Firm 17 & $\begin{array}{l}\text { Foods \& } \\
\text { Beverages }\end{array}$ & $\begin{array}{l}\text { A large established multinational firm } \\
\text { with strong resources; one of the world } \\
\text { leaders in its sector. }\end{array}$ & $\begin{array}{l}\text { At certain points in its history has shaped consumer preferences by introducing iconic } \\
\text { products; has driven the behavior of its distributors, exploiting its negotiating power; has } \\
\text { successfully driven its multipliers (e.g., wider society, investors, and media) via } \\
\text { communication campaigns and sponsorships. }\end{array}$ \\
\hline Firm 18 & Cosmetics & $\begin{array}{l}\text { A large established firm of domestic } \\
\text { background with strong resources and } \\
\text { activities in more than } 30 \text { countries. }\end{array}$ & $\begin{array}{l}\text { Has shifted consumer preferences from chemical-based products to natural products; has } \\
\text { driven the behavior of its distributors, exploiting its negotiating power; has successfully driven } \\
\text { its multipliers (e.g., wider society, investors, and media). }\end{array}$ \\
\hline Firm 19 & $\begin{array}{l}\text { High } \\
\text { technology, } \\
\text { Retailing }\end{array}$ & $\begin{array}{l}\text { A large established domestic firm, with } \\
\text { strong resources; one of the market } \\
\text { leaders in its sector. }\end{array}$ & $\begin{array}{l}\text { Has heavily invested in technology and innovation; has successfully driven both its suppliers } \\
\text { (via advantageous agreements) and its multipliers (e.g., wider society, investors, and media), } \\
\text { therefore building a powerful brand name. }\end{array}$ \\
\hline Firm 20 & $\begin{array}{l}\text { High } \\
\text { technology, } \\
\text { Tourism }\end{array}$ & $\begin{array}{l}\text { A large established multinational firm, } \\
\text { with strong resources; one of the world } \\
\text { leaders in its sector. }\end{array}$ & $\begin{array}{l}\text { Has revolutionized the tourism sector, by developing an online platform for booking } \\
\text { accommodation, therefore, driving customer preferences. Has influenced many providers of } \\
\text { touristic products, by exploiting its power. }\end{array}$ \\
\hline
\end{tabular}


Table 4: Overview of main findings

\begin{tabular}{|l|l|l|l|}
\hline \multicolumn{1}{|c|}{$\begin{array}{c}\text { Top Management } \\
\text { Unaided Section A1 }\end{array}$} & \multicolumn{1}{|c|}{$\begin{array}{c}\text { Top Management } \\
\text { Aided Section A2 }\end{array}$} & $\begin{array}{c}\text { Middle Management } \\
\text { Unaided Section B1 }\end{array}$ & $\begin{array}{c}\text { Middle Management } \\
\text { Aided Section B2 }\end{array}$ \\
\hline 1. Open-Minded policy & 1. Transformational Leadership & 1. Open-Minded Policy & 1. Intrapreneurship \\
\hline $\begin{array}{l}\text { 2. Having Strong Vision } \\
\text { 3. Strategic Human Resource } \\
\text { Management }\end{array}$ & 2. Fostering Creativity & 2. Expertise & 2. Creativity \\
\hline 4. Transformational Leadership & 3. Having Strong Vision & 3. Transformational Leadership & 3. Flexibility \\
\hline $\begin{array}{l}\text { 5. Prediction Skills and } \\
\text { Insightfulness }\end{array}$ & & 4. Commitment & 4. Transformational Leadership \\
\hline
\end{tabular}


Figure 1: Conceptual framework

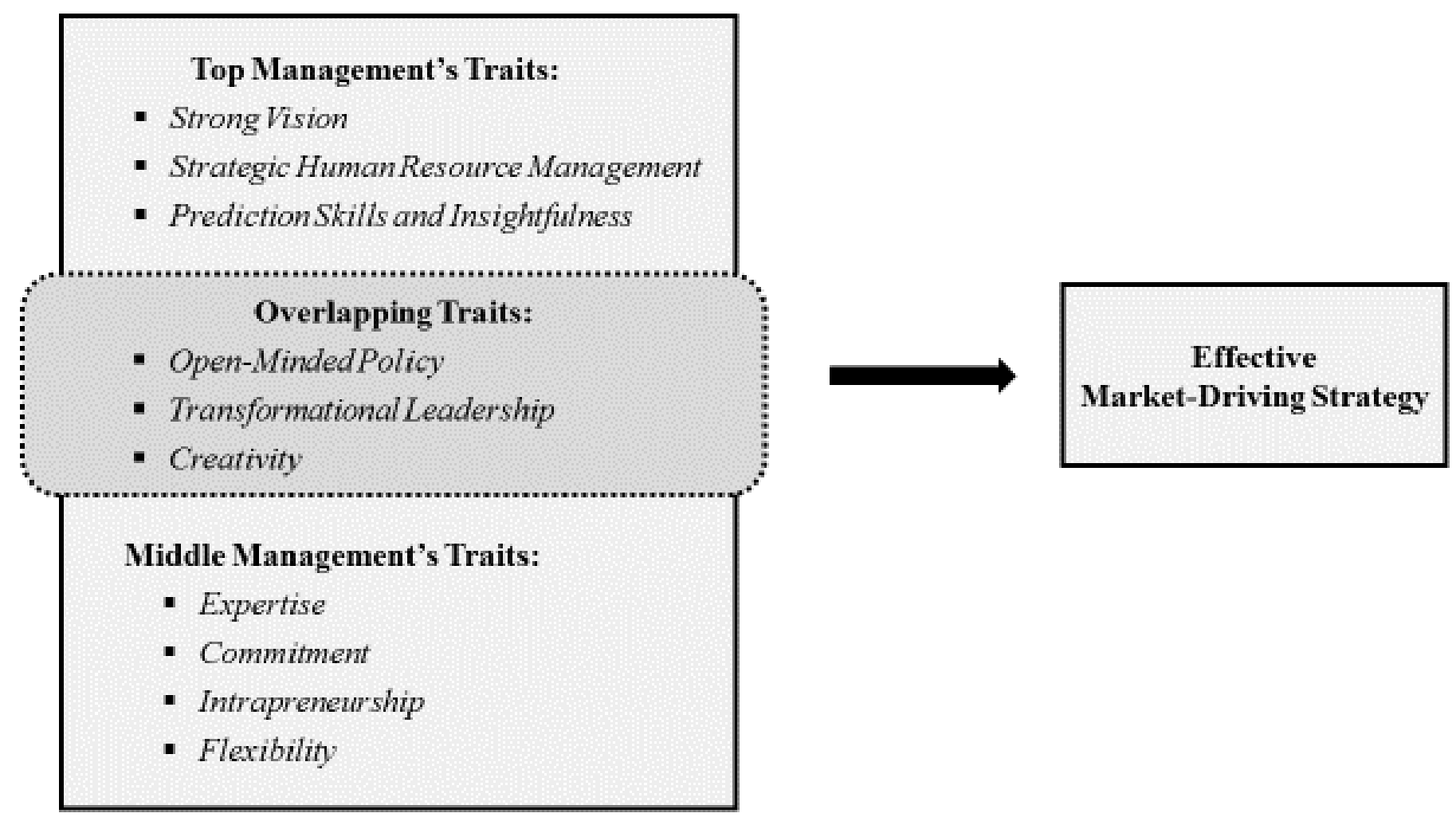

